\title{
First report of Fusarium equiseti causing wilt on lentils (Lens culinaris Medik.) in Pakistan
}

\author{
Khola Rafique ${ }^{1,2} \cdot$ Chaudhary Abdul Rauf $^{2} \cdot$ Seogchan Kang ${ }^{3}$ \\ Received: 1 April 2019 / Accepted: 25 November 2019/Published online: 10 December 2019 \\ (C) Società Italiana di Patologia Vegetale (S.I.Pa.V.) 2019
}

Keywords Fusarium equiseti $\cdot$ Lentil $\cdot$ Morphology $\cdot$ Translation elongation factor- 1 alpha $\cdot$ Pathogenicity

Lentils (Lens culinaris) showing wilt symptoms including yellowing, plant stunting and vascular discoloration were observed at the production sites of Jhelum district of Punjab province. During 2011-12 and 2012-13, the disease incidence evaluated was $8 \%$ and $20 \%$, respectively. Small root pieces disinfected with $1 \%$ sodium hypochlorite for $2 \mathrm{~min}$ were placed on potato dextrose agar (PDA) at $25{ }^{\circ} \mathrm{C}$ for 7 days. Colonies presented a compact to fluffy mycelium initially creamy white, then characterized by a pale brown pigmentation. Purified cultures produced slightly curved macroconidia $(16.9-32 \times 2.5-3.8 \mu \mathrm{m})$ with 5 septa, elongated apical and foot-shaped basal cell. Chlamydospores $(7.0-12.8 \mu \mathrm{m})$ were spherical, intercalary and solitary or in short chains. The observed characters matches with the species description of Fusarium equiseti (Corda) Saccardo (Leslie and Summerell 2006). To confirm this putative identification, DNA was extracted (Cenis 1992; Abd-Elsalam et al. 2003) for the amplification of $700 \mathrm{bp}$ translation elongation factor (TEF1- $\alpha$ ) gene region using EF1/EF2 primers (Geiser et al. 2004). Sequences were deposited in GenBank (Accession Nos. KR108316 to KR108322) and BLAST analysis showed 99\% identity to those derived from $F$. equiseti. Pathogenicity of isolates was evaluated in a greenhouse at $25 \pm 2{ }^{\circ} \mathrm{C}$ by inoculating roots of susceptible lentil line (NARC-08-1) seedlings in $60 \mathrm{~mL}$ spore suspension $(1 \times$

Khola Rafique

kholarafique@gmail.com

1 Pest Warning and Quality Control of Pesticides, Department of Agriculture, Lahore, Punjab 54000, Pakistan

2 Department of Plant Pathology, Pir Mehr Ali Shah Arid Agriculture University, Rawalpindi 46000, Pakistan

3 Department of Plant Pathology and Environmental Microbiology, The Pennsylvania State University, University Park, PA 16802, USA
$10^{7}$ conidia/ $\mathrm{mL}$ ), while control plants were treated with sterile water. Clear wilt symptoms were observed in all the fungal inoculated plants after 20-25 days with $100 \%$ incidence and $30 \%$ severity index (Kranz 1988) while control plants were symptomless. F. equiseti re-isolated from all the inoculated plants exhibited morphomolecular characters similar to those observed among the isolates. To our knowledge, this is the first report of F. equiseti causing wilt on lentils in Pakistan.

\section{References}

Abd-Elsalam KA, Schnieder F, Guo JR (2003) A modified DNA extraction minipreparation protocol for Fusarium isolates. J Rapid Methods Autom Microbiol 11:75-79

Cenis J (1992) Rapid extraction of fungal DNA for PCR amplification. Nucleic Acids Res 20:2380

Geiser DM, Jimenez-Gasco MDM, Kang S, Makalowska I, Veeraraghavan N, Ward T, Zhang N, Kuldau G, O'donnell K (2004) FUSARIUM-ID v. 1.0: a DNA sequence database for identifying Fusarium. Eur J Plant Pathol 110:473-479

Kranz J (1988) Measuring plant disease. In Experimental techniques in plant disease epidemiology. Springer, pp 35-50

Leslie JF, Summerell BA (2006) The Fusarium laboratory manual, 1st edn. Wiley-Blackwell Publishing Professional, Ames

Publisher's note Springer Nature remains neutral with regard to jurisdictional claims in published maps and institutional affiliations. 